\title{
Taxonomic notes on species of Passiflora subgenus Astrophea (Passifloraceae s.S.)
}

\section{Ana Carolina Mezzonato-Pires ${ }^{1 *}$ (1), Michaele Alvim Milward-de-Azevedo² ${ }^{2}$, Cláudia Barbieri Ferreira Mendonça ${ }^{1}$ (i) and Vania Gonçalves-Esteves ${ }^{1}$ (i)}

Received: November 21, 2018

Accepted: January 17, 2019

\begin{abstract}
The subgenus Astrophea is one of the most critical and neglected subgenera of the genus Passiflora. Seven Brazilian species of $P$. subg. Astrophea were found to be in need of typification. Lectotypes are designated for the following names: Passiflora cauliflora, P. leptopoda, P. ceratocarpa, P. faroana, P. rhamnifolia, P. sclerophylla and P. tessmannii. An epitype was also designated for the name P. tessmannii. In addition, Passiflora alliacea was synonymized with Passiflora pentagona.
\end{abstract}

Keywords: Brazilian species, epitype, lectotype, nomenclature, taxonomy

\section{Introduction}

The genus Passiflora, described by Carl Linnaeus in Species Plantarum (Linnaeus 1753), is the most important genus of the family Passifloraceae sensu stricto as it comprises a high number of species, several of which are of great economic significance due to their nutritional, medicinal and ornamental uses.

The genus has five subgenera, according to Feuillet \& MacDougal (2003) and Krosnick et al. (2009), four of which are monophyletic: P. subg. Astrophea, P. subg. Decaloba, P. subg. Passiflora and P. subg. Tetrapathea. Muschner et al. (2003), Zamberlan (2007) and Krosnick et al. (2013) all consider P. subg. Deidamioides to be non-monophyletic.

Passiflora subg. Astrophea stands out because it contains about 60 Neotropical species, with their center of diversity being in lowland areas of northern South America (Ulmer \& MacDougal 2004). Brazil, with 31 species, is the country with the highest number of taxa (Mezzonato-Pires 2017). Besides having geographical distributions that include places that are difficult to access, species of Astrophea have morphological characteristics that make it difficult to see and collect them in the field. Such characteristics include their liana habit, which allows them to even reach above the canopies of tall trees, as well as their entire leaf blades that possess two inconspicuous leaf glands.

Thus, P. subg. Astrophea represents the largest gap in the knowledge of the genus Passiflora, and thus studies that add to the collective knowledge of these species are needed. This work was carried out as apart of the project "Flora of Brazil 2020", whose objective is to provide data on type material of the plants described in Brazil. As a result, seven names belonging to $P$. subg. Astrophea were found in need of lectotypification, and a new synonym is proposed.

\section{Materials and methods}

The study was based on type material and/or photographs of types provided by the following herbaria: B, C, F, INPA,

1 Departamento de Botânica, Museu Nacional, Universidade Federal do Rio de Janeiro, 20940-040, Rio de Janeiro, RJ, Brazil

2 Departamento de Ciências do Meio Ambiente, Instituto Três Rios, Universidade Federal Rural do Rio de Janeiro, 25802-100, Três Rios, RJ, Brazil

* Corresponding author: carolina.mezzonato@gmail.com 
G, K, MBM, MG, RB, S, UEC, US (acronyms are according to Thiers 2018).

\section{Typifications}

1. Passiflora cauliflora Harms, Verh. Bot. Vereins Prov. Brandenburg 48: 185. 1907 -Lectotype (designated here): Peru, Loreto, Cerro de Escaler 1300m, I/1903 Ule 6679 (MG!; MG [photo!]).

The collector of the type of $P$. cauliflora was erroneously listed as Tessmann by the site http://www.tropicos.org, (whose material of "photo-negatives" is deposited in herbaria $\mathrm{B}$ and $\mathrm{F}$ ). Based on the protolog the collector was Ule (Ule 6679). According to Escobar (1990), the curator of herbarium B, reported the deposited type specimen was destroyed during World War II. Therefore, the material of MG, that was previously considered an isotype, is herein lectotypified.

2. Passiflora leptopoda Harms, Notizbl. Bot. Gart. BerlinDahlem 6: 347. 1917-Lectotype (designated here): Brazil, Roraima (Rio Branco), Serra de Carauma, fl., XI/1908, Ule 7708 (MG!; isolectotype: G, US [photo!]).

Two syntypes are mentioned in the protolog of $P$. leptopoda. According to Killip (1938) the type of P. leptopoda was deposited in B, but according to Escobar (1990), this material was destroyed. Although there is still a small blackand-white photograph on the website http://www.tropicos. org, it was considered more prudent to lectotypify the material deposited in $M G$ that was previously recognized as an isosyntype.

3. Passiflora ceratocarpa F.Silveira, Arch. Jard. Bot. Rio de Janeiro 5: 221, pl. 30. 1930 -Lectotype (designated here): Brazil, Pará, Belém, 23/XI/1926 (fl.), A. Ducke 17333 (RB!, RB-00542761, flower); remaining syntypes: Brazil, Pará, Belém, 31/I/1923 (fr.), A. Ducke 17333 (RB!, RB-00542761, fruit); isolectotypes: RB! (RB-00557231), G (photo!), S (photo!, flower), K (photo!, K-000323317, flower), US (photo!, flower); remaining isosyntypes: RB! (RB00557230, fruit), S (photo!, fruit), K (photo!, K-000323317, fruit), US (photo!, fruit).

The type material for Passiflora ceratocarpa F. Silveira was collected by A. Ducke and received the RB number 17333. However, two dates are found on the label; one for the collection with fruits in 1923, and the other for the collection of flowers in 1926. According to the work of the princeps, this last collection was derived from material collected by Ducke in the Amazon and cultivated in the Botanical Garden of Rio de Janeiro. According to the international code for nomenclature of Algae, Fungi and Plants (Sehnzen Code 2018) - following the articles, 8.2, footnote 2 and example 3 - if material is collected at more than one time, it can not be accepted as a type. We thus conclude that the Ducke collections of 1923 and 1926 are syntypes. Therefore, the material of RB17333 (pro part, floral branch) is lectotypified.

4. Passiflora faroana Harms, Notizbl. Bot. Gart. BerlinDahlem 10: 809. 1929-Lectotype (designated here): Brazil, Pará, Campina de Infiry, Lago Faro, fl., 19/V/1911, A. Ducke 325 (RB!; isolectotype: K, US, F [photo!])

Two collections by A. Ducke were cited as syntypes in the protolog of P. faroana: A. Ducke 325 from Campina Infiry near Lake Faro, Pará; and A. Ducke 675 from Campo de Tigre, Faro, Pará. The lectotype (A. Ducke 325) designated by Killip (1938) was deposited at B and was destroyed during World War II, according to Escobar (1990). Thus, it became necessary to designate another lectotype whose specimen is deposited in RB. It is important to note that during the first lectotypification, Killip (1938) misidentified the location and wrote "Jupiry" instead of "Infiry", which is the correct name of the collection locality.

5. Passiflora rhamnifolia Mast., Fl. Bras.13(1): 545, 575. 1872 - Lectotype (designated here): Brazil, São Paulo, Cubatão, s.d., Sello 2148 (US).

In describing P. rhamnifolia, Masters (1872) cited two collections as syntypes - Sello 2148 and Sello 2125 both from the municipality of Cubatão, state of São Paulo (however, it is believed that due to a misunderstanding, the state of Minas Gerais was written in the protolog). Killip (1938) lectotypified Sello 2148, which was deposited in B. According to Escobar (1990), the material was destroyed. Thus, a new lectotype is here indicated - the specimen Sello 2148 of US.

6. Passiflora sclerophylla Harms, Notizbl. Bot. Gart. Berlin-Dahlem 6: 347.1917 - Lectotype (designated here): Brazil, Roraima, XII/1909, Ule 8667 (MG!; isolectotype: G, $\mathrm{K}, \mathrm{K}$ [photo!]).

Two collections of syntypes are cited in the protolog of P. sclerophylla; one from Guyana, Venezuela and Roraima, collected by Ule (Ule 8667), and the other from Roraima, collected by Schomburgk (Schomburgk 986). The former material was later designated by Killip (1938) as a lectotype (Ule 8667) and deposited in B, where it was destroyed. Thus, we assign a new lectotype, deposited in MG.

7. Passiflora tessmannii Harms, Notizbl. Bot. Gart. BerlinDahlem 9: 978. 1926 - Lectotype (designated here): Peru, Loreto, Iquitos, mouth of Santiago River, Oct 1924, fl., G. Tessmannii 4385 (fragmento e fotografia US [photo!]) - Epitype (designated here): Brazil, Amazonas, ManausItacoatiara, Reserva Florestal Ducke, km 26, 02 ${ }^{\circ} 53^{\prime} \mathrm{S}$, 5958'W, 10/X/1995, C.A. Sothers \& E.C. Pereira 612; (INPA!, isoepitype: MBM!, MG!, UEC!) .

The holotype designated by Harms (Tessmann 4385) for P. tessmannii was deposited in B. There are fragments and a black-and-white photograph of this specimen in the US. The 
holotype deposited in B was destroyed, according to Escobar (1990), and through consultation of the virtual collection available from B (http://ww2.bgbm.org/herbarium/default. (fm), no type material was found for this species. Therefore, the remaining fragments of the isotype deposited in US are herein lectotypified. The existing black-and-white photograph of $P$. tessmannii does not faithfully depict its main morphological characteristics, for example: corona with two series of filaments; external filaments linear with broadly falcate apices with attenuate tips, and subulate internal filaments; and the presence of a trochlea. Since the lectotype alone does not present the full set of diagnostic characteristics, C. A. Sothers \& E. C. Pereira 612, material collected in the Adolpho Ducke Forest Reserve, state of Amazonas, Brazil, was designated as an epitype, which is deposited in INPA.

\section{Synonymy}

1. Passiflora pentagona Mast., Fl. Bras. 13(1): 575, pl. 108, f. 2. 1872 - Type: Brasil, s.d., Rio de Janeiro, Lund 1162 (lectotype: C designated by Killip (1938); C! [photo!]). Passiflora alliacea Barb. Rodr., Contr. Jard. Bot. Rio de Janeiro 1: 59. 1901, syn. nov. - Lectotype: Brazil, Rio de Janeiro, Restinga, Barbosa Rodrigues s.n.,
Contributions du Jardin Botanique de Rio de Janeiro, vol.1, tab. 7 (1901).

The following syntypes are mentioned in the protolog for the species: Lund 1162, Martius 1221 and Luschnath s.n. from Rio de Janeiro; Weddell 1216 from the province of Minarum; and Sello s.n. from an unspecified area in southern Brazil. Killip (1938) proposed the lectotypification of Warming 1162 (C) for this species. However, the label of the lectotype indicates Lund as the collector, suggesting that there was a mistake during the writing of the name of the collector.

Passiflora alliacea Barb.Rodr. was described in 1901, with the type locality being a restinga environment in Rio de Janeiro. It was recorded as blooming in December and fruiting in January. The specific epithet alliacea was applied based on the garlic smell released by its fruits. After thorough comparative analyses of the type descriptions, specimens and illustrations, we conclude that $P$. alliacea is conspecific with P. pentagona (Fig. 1). The diagnostic characteristics described for $P$. alliacea are retroflexed flowers with a 6-angled hypanthium and broadly bifid internal corona filaments; all of which are also found in P. pentagona. In his work on Passifloraceae of the Americas, Killip (1938) noted that distinguishing these species might not be possible, although he did not synonymize them. Therefore, P. alliacea is herein designated a new synonym of $P$. pentagona.

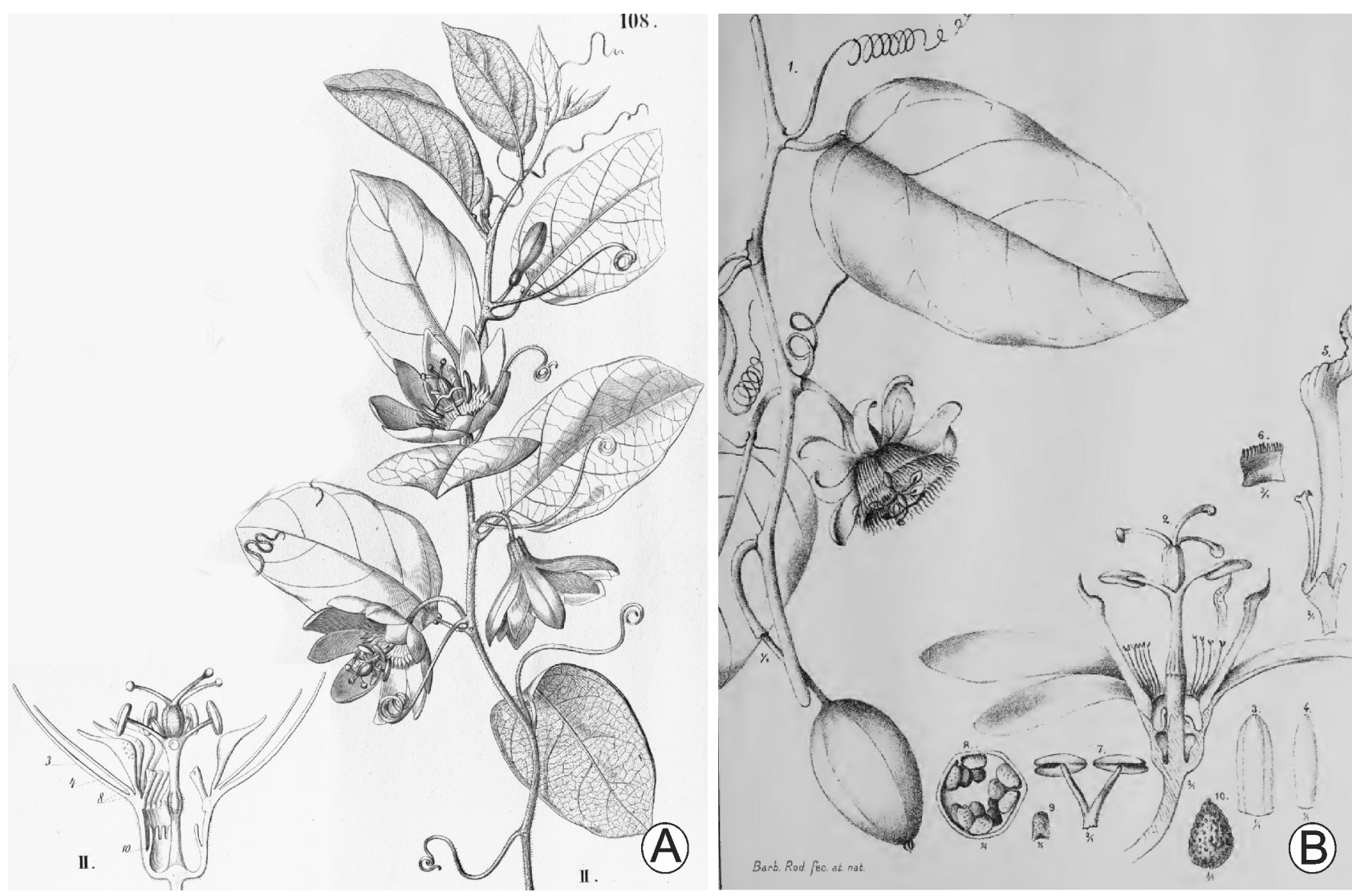

Figure 1. Illustrations taken from the princeps work. A. Passiflora pentagona Mast. (Masters 1872). B. Passiflora alliacea Barb. Rodr. (Barbosa Rodrigues 1901). 


\section{Ana Carolina Mezzonato-Pires, Michaele Alvim Milward-de-Azevedo, Cláudia Barbieri Ferreira Mendonça and Vania Gonçalves-Esteves}

The diagnostic characteristics of P. pentagona are: leaf blades that are oval-elliptical, ovate, ovate-oblong, adaxially glabrous (except along the midvein) abaxially puberulous, and with transparent trichomes; solitary greenish-white flowers with cylindrical-campanulate hypanthia; corona with two sets of filaments that are beige with burgundy spots, the first series being dolabriform with long and attenuated apicies and slightly undulate margins, the second series being linear with bifid or clavate apices; operculum that is erect, filamentous, not tubular, inserted, and with a fimbriate apex; and fusiform trochlea with a spotted region above which are trichomes.

\section{Acknowledgements}

The first author thanks the Doctoral scholarship granted by CNPq (Conselho Nacional de Desenvolvimento Científico e Tecnológico). Vania Gonçalves-Esteves thanks CNPq for a research grant that supported this work.

\section{References}

Escobar LA. 1990. Una Revision Taxonomica de Passiflora subgenero Astrophea, Passifloraceae. PhD Thesis, Universidad de Antioquia, Antioquia.

Feuillet C, MacDougal J. 2003. A new infrageneric classification of Passiflora L. (Passifloraceae). Passiflora The Journal \& Newsletter of Passiflora Society International 13: 34-38.
Killip EP. 1938. The American species of Passifloraceae. Publication Field Museum of Natural History, Botanical Series 19: 1-613.

Krosnick SE, Ford AJ, Freudenstein JV. 2009. Taxonomic revision of Passiflora subgenus Tetrapathea including the monotypic genera Hollrungia and Tetrapathea (Passifloraceae), and a new species of Passiflora. Systematic Botany 34: 375-385.

Krosnick SE, Porter-Utley KE, MacDougal JM, Jorgensen PM, Mcdade LA. 2013. New insights into the evolution of Passiflora subgenus Decaloba (Passifloraceae): Phylogenetic relationships and morphological synapomorphies. Systematic Botany 38: 692-713.

Linnaeus C. 1753. Species Plantarum: exhibentes plantas rite cognitas, ad genera relatas, cum differentiis specificis, nominibus trivialibus, synonymis selectis, locis natalibus, secundum systema sexuale digestas. Holmae, Impensis Laurentii Salvii. https://doi.org/10.5962/bhl. title.669

Masters MT. 1872. Passifloraceae. In: Martius CFP, Eichler AW, Urban I. (eds.) Flora Brasiliensis: enumeratio plantarum in Brasilia hactenus detectarum :quas suis aliorumque botanicorum studiis descriptas et methodo naturali digestas partim icone illustratas. Munchen, R. Oldenbourg. p. 529-628.

Mezzonato-Pires AC. 2017. Sistemática de Passiflora Subgênero Astrophea: Morfologia, palinologia e taxonomia. PhD Thesis, Universidade Federal do Rio de Janeiro, Rio de Janeiro.

Muschner VC, Lorenz AP, Cervi AC, Bonatto SL, Souza-Chies TT, Salzano FM, Freitas LB. 2003. A first molecular phylogenetic analysis of Passiflora (Passifloraceae). American Journal of Botany 90: 1229-1238.

Thiers B. [continuously updated]. 2018. Index Herbariorum: a global directory of public herbaria and associated staff. New York, New York Botanical Garden's Virtual Herbarium. http://sweetgum.nybg. org/ih/. 15 Sep. 2018.

Ulmer T, MacDougal JM. 2004. Passiflora: Passionflowers of the world. Cambridge, Timber Press.

Zamberlan PM. 2007. Filogenia de Passiflora L. (Passifloraceae): questões infra-subgenéricas. PhD Thesis, Universidade Federal do Rio Grande do Sul, Porto Alegre. 